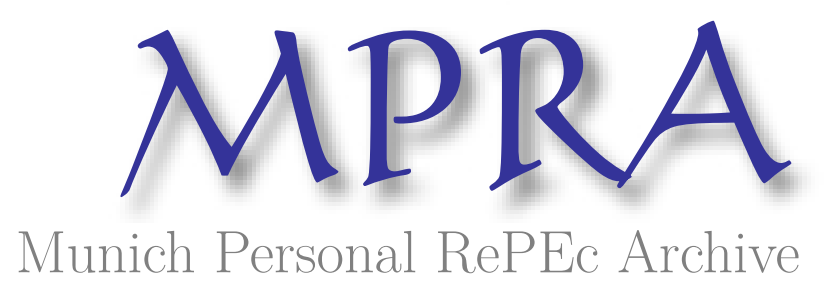

\title{
Ranking Italian Universities and Other Research Institutions Taking Into Account Public Economics Publications
}

Molero, Juan Carlos and Pujol, Francesc

24 July 2004

Online at https://mpra.ub.uni-muenchen.de/8055/

MPRA Paper No. 8055, posted 03 Apr 2008 04:50 UTC 


\title{
Ranking Italian Universities and Other Research Institutions Taking Into Account Public Economics Publications.
}

\author{
Juan Carlos Molero \\ Francesc Pujol \\ Department of Economics \\ University of Navarra
}

July 17, 2004

\section{Correspondent author:}

Juan Carlos Molero

Department of Economics

University of Navarra

Edificio de Bibliotecas (Entrada Este)

E - 31080 Pamplona

SPAIN

E-mail: jcmolero@unav.es

Tel: +34 948425625

Fax: +34948425626 


\begin{abstract}
The different ways to rank universities regarding their research production include a great number of factors. The quality of journals where faculty members are publishing is one of the most relevant aspects in order to determine the quality of the affiliation institution.

Among other more traditional ways determining the quality of journals, this paper takes into account a new one based on the publishing behavior of top ranked authors, supposing a matching model approach among journals and authors. Using this methodology, the article establishes a ranking of the Italian universities and other research institutions regarding Public Economic Journals.
\end{abstract}

Keywords: matching model, ranking public economic journals, Italian universities.

JEL: C78, H00, I29, Z00 


\section{Introduction}

The goal of this paper is to offer a new kind of raking, not only following a new approach regarding the journals where professors affiliated to those universities are publishing, but also focussing the analysis just for the Public Economics sub-discipline. The justification of this approach is that most of the rankings presented in the literature are dealing just with general economic journals, being not many the ones focussed on the different sub-domains of economics. We can not forget that this is nowadays more important, since the degree of specialization is growing even among the different sub-fields of economics ${ }^{1}$.

In order to undertake this goal, we introduce first how the new ranking methodology works. Second, we offer a brief explanation comparing Europe with other different areas of the world concerning the publication market for some specific journals. In this section, we also analyze the role of Italy comparing with other countries in Europe. Third, we rank Italian universities regarding Public Economics publications. We finally conclude.

\section{Explaining a new ranking methodology}

As in other areas of knowledge, in Economics there are two main ways to undertake the evaluation of the academic publishing market. To estimate the impact factor of a journal taking into account the weight given by peers, or to analyse the number of citations that

\footnotetext{
${ }^{1}$ In this sense, in the study about Journals of Economics, Stigler et al (1995) includes an examination of the degree of specialization among the different sub-fields of economics.
} 
articles published in a concrete journal are receiving from international journals with recognized prestige.

The citation approach offers reliable rankings dealing with journals concerning Economics and Business Administration field. Among others, the rankings developed by Liebowitz \& Palmer (1984) and Laband \& Piette (1994), published by the Journal of Economic Literature, use the Social Sciences Citation Index (SSCI) of the Journal Citation Reports in order to obtain the impact adjusted citations for economic journals. The problem with this approach is that auto-citations are not excluded, although we are more concerned about the weaker results obtained using this method regarding national or subdiscipline journals, which moreover is where we will focus the present research. In this sense, Davis (1998) criticizes the citation approach, and mainly the work of Laband \& Piette (1994), because he says this method easily can lead second-tier general-interest journals and special and subfields journals to worse positions that they should be when they are compared with generalinterest journals. Then, and among other authors, Barret (2000) supports the idea that subdiscipline classifications are needed.

Regarding optional approaches dealing with subdiscipline journals, the by peer ranking method could appear like the right solution, although at the same time it also presents several problems. In this sense, and comparing this approach with the citation method, Mason points out that:

"There are several reasons to distinguish objective and subjective rankings. First, a profession well-known for assuming rationally ought to ensure that is members are rational in practice. Second, administrators and faculty often make assertions such 
as 'We all know which journals are the best' or 'There is no need to list acceptable journals, because we all know what they are'. No empirical study has attempted to validate such statements. Third, when economists conduct literature searches, they are likely to seek those journals that they hold in high esteem" (MASON et al., 1997, pp. 69-70)

All these reasons could make the results obtained using this approach for subdiscipline rankings least confident that the ones through the citation approach.

Taking into account the problems showed by the methods described above, we use a new alternative methodology that ranks the academic publishing market following a matching model approach among authors and journals ${ }^{2}$. In this approach, authors are offering potential publications to journals, which are the ones demanding manuscripts. We take into account just quality variable to be maximized for both, authors and journals. The attributes in quality are not fixed in time for journals, but we do fix quality attributions for authors ${ }^{3}$.

\footnotetext{
${ }^{2}$ This matching process approach is widely explained in Pujol (2003)

${ }^{3}$ We suppose "author's quality attributions are fixed in time, as they depend mainly on their intelligence and creativity, which we consider as exogenous, and education, that we also consider exogenous because we suppose that authors enter into the publishing market when the formal education process is concluded. The maximal scientific quality of submitted papers will be directly linked to the researcher intrinsic scientific capabilities [...] It is clear that creativity and, in a lower extent, also intelligence and education can evolve in the midst of an academic carrier, in a upward trend in some cases and, more frequently, in a downward process, but we think that is not necessary to model these variables as endogenous in our model, as this specific issue is not directly related with the main purpose of this research" (PUJOL, 2003, p. 9)
} 
Then, and although we will go deeper on this aspect below, in general we could say that quality will be an exogenous variable for authors, but endogenous for journals. Supply will include top (blue ribbon authors), good, mid and low quality authors, all fixed in time. In the same manner, in the demand we will distinguish core (blue ribbon), top tier, second order and low quality journals, according to the quality of articles published on journals.

Once supply and demand sides have been described, we establish now how the matching strategy is working.

In the supply side, we could say that 'Blue Ribbon journals (BRJ) top authors' and 'top authors' will produce 'reference manuscripts' and 'good manuscripts'. 'BRJ good authors' and 'good authors' will provide 'good manuscripts' and 'average manuscripts'. 'Average authors' will offer 'average manuscripts' and 'poor manuscripts' to the market. And 'low profile authors' will produce just 'poor manuscripts'. All authors try to send their publications to best journals where they can be accepted, according to their auto perception of the intrinsic quality of their articles and their knowledge about how is ranked the quality of economic journals ${ }^{4}$. If the author overestimates his paper, the reviewing process (in theory of an academic publishing free market) will lead the article to the more appropriate journal.

\footnotetext{
${ }^{4}$ In this approach we believe that "the academic market, at least in the Economics field, has developed these last decades a lot of results concerning journal rankings, which has a direct effect an increase on transparency and information about the quality factor of journals"... "Lack of information is mainly concentrated amongst mid and low class researchers, then the actual risks of systematic mismatching in the publishing market tend to disappear" (PUJOL, 2003, p. 8)
} 
In the demand side, 'Blue Ribbon journals' would receive for publication 'reference manuscripts' and 'good manuscripts'. 'Top tiers \& subdiscipline top journals' could get 'reference manuscripts', 'good manuscripts' and 'average manuscripts'. 'Average journals' would obtain 'good manuscripts', 'average manuscripts' and 'poor manuscripts'. And 'poor quality journals' will attract just 'poor manuscripts'. In the same manner as the supply side, all journals are trying to maximize their quality (and then their scientific impact) publishing the best manuscripts they can. For this reason, a journal that wants to become prestigeous has to attract high quality articles and, if it is possible, even written by high quality authors - 'BRJ top authors' or 'BRJ good authors'. The model proposed sets up that a high quality author is the one who publishes in journals that already have high quality and scientific impact: BRJ. In order to undertake this issue and raise their standards of publication, editorial boards impose more requirements to potential manuscripts for publication.

According to the explanation above, it is considered that quality of journals is an endogenous variable finally determined by authors' behavior, since high quality authors drive the matching process. But, there is one exception for Blue Ribbon journals, since BRJ are driving at the same time high quality authors. Then, just regarding BRJ, quality will be an exogenous variable for journals and endogenous for authors. Once we set up this and concerning the rest of journals to be analyzed, quality will be an exogenous variable for authors and endogenous for journals.

As a starting point, the new model used in this paper is based on Blue Ribbon journals, which in the economics field are very well known and accepted in this sense. Because, as 
we mentioned, the right method to measure the impact of top ranked journals is the citation approach, we follow one of the most recent estimations by Kalaitzidakis et al. (2003). This estimation is a Revised Version of the JCR Index for articles published in the period that goes from 1990 to 2001 both years included. According to this research the impact factor points will rank the main Blue Ribbon journals we have selected as follows: American Economic Review (100.0), Econometrica (96.8), Journal of Political Economy (65.2), Journal of Economic Theory (58.8), Quarterly Journal of Economics (58.1), Review of Economic Studies (45.2), Economic Journal (20.7), and Journal of Economic Literature $(18.8)$

Weighted BRJ according to Kalaitzidakis et al.'s punctuation, the new model ranks the 4,681 BRJ researchers (high quality authors: 'BRJ top authors' or 'BRJ good authors') publishing in these journals during the mentioned period (1990-2001). For instance, each time an author publishes one article in Econometrica gets 96.8 points. If the paper has $m$ co-authors, each one will get $96.8 / \mathrm{m}$ points publishing one article in this journal.

Since high quality researches drive the matching process methodology, the evaluation of any other journal is based on the publishing behavior of these 4,681 BRJ authors publishing in these eight BRJ from 1990 to 2001.

Then it comes the second step of the methodology. Applying a cluster analysis over a list of 46 selected journals, including Public Economic and other neighbor journals (see column 4

\footnotetext{
${ }^{5}$ Pujol, 2003, p. 38 includes the list of the 300 best-ranked BRJ authors.
} 
in annex 1), we obtain just 31 strictly Public Economic journals all included in the database Econlit (in bold characters also in column 4 annex 1)

According to the relative number of articles published by BRJ authors in these 46 journals from 1995 to 2001 both years included, column 1 in annex 1 includes the ranking for the all set of journals. Column 2 includes a more restricted ranking (in remarked characters) just for the 31 Public Economic journals ('PE Core'). The number of articles published by each journal appears in column 3. The number of points each journal receives is included in column 5, where again we have remarked Public Economic journals since they are really the ones on which we will focus our research. For instance, Journal of Public Economics JPE- (first in the ranking concerning Public Economics journals) reaches 64.84. It means that authors publishing in JPE have published other papers in BR journals between 1990 and 2001 in an amount equivalent to 64.84 impact factor points as measured by Kalaitzidakis et al (2003) reference, but following a specific kind of punctuation based on the behavior of BRJ authors ${ }^{6}$.

${ }^{6}$ The exact calculation used to fix the impact of each Public Economic journal, and then also for the neighbor journals is as follows:

$P E I_{i}=\frac{\sum_{a=1}^{n} P E_{a i} * B R_{a}}{\sum_{a=1}^{n} P E_{a i}}$

"Where $P E I_{i}$ is the Public Economics Impact value of each $i$ journal selected for ranking. $P E_{a i}$ corresponds to the number of articles published by the author $a$ in the Public Economics journal $i$, times $B R_{a}$, the impact 
As a summary, let us say that we have now a new ranking to be used concerning Public Economics journals regarding the number of BRJ authors publishing on them. The Journal of Public Economics is leading the ranking, while the Bulletin for International Fiscal Documentation reaches the last position. Based on this ranking, we have analyzed more deeply the 6,102 articles published in the 31 Public Economics journals (see bottom of column 3, annex 1) during the period 1995-2001.

At this point we have two purposes concerning next sections of this paper. First, to study the articles published in this list of journals taking into account the origin of the article worldwide and by countries, paying special attention to the case of Italy. Second, to rank universities and other research institutions in Italy.

\section{The role of Italy within the Public Economics journals production market}

Looking at the publications regarding Public Economic journals by different areas of the world, we choose: USA, West Europe, UK (the percentage for UK is included within the total percentage for West Europe), Asia (except Japan), Japan, East Europe, and Latin America. Table 1 shows by percentages and for each journal the distribution of authors' affiliation by areas of the world. But, because some papers are produced by international increase the impact factor of the Public Economics journal $i$. The term $n$ corresponds to the number of authors having published in PE journal $i$ " (PUJOL, 2003, p. 21) 
organizations, percentages for each one of the journals do not have to summarize $100 \%$. Then, we have finally analyzed just $89.71 \%$ of the 6,102 articles, which means 5,474 articles.

[Table 1 about here]

Taking a look of data included in table 1, first thing to be enlightened is that, with a few exceptions, USA (Mean PE journals is $46.95 \%$, as a Mean of publications for all 31 journals) and West Europe (Mean PE journals is 37.73\%) are the areas getting the bigger percentages, no matter if the journal is up or down ranked.

Especially concerning top five journals almost half or even more of total articles come from American authors; for instance, $56.03 \%$ of Economics and Politics ( $3^{\text {rd }}$ in ranking) and $91.10 \%$ of National Tax Journal (5 $5^{\text {th }}$ in ranking). But also USA gets $68.07 \%$ of the publications of Journal of Regulatory Economics ( $10^{\text {th }}$ in ranking), $90.58 \%$ of Journal of Policy Analysis and Management (13 ${ }^{\text {th }}$ in ranking), $97.68 \%$ of Social Security Bulletin $\left(24^{\text {th }}\right.$ in ranking), and $90.16 \%$ of Bulletin for International Fiscal Documentation $\left(31^{\text {st }}\right.$ in ranking). The justification regarding some of these percentages for USA is that some of these journals are focussed on American issues. For instance: National Tax Journal, Journal of Policy Analysis and Management or Social Security Bulleting, which is in fact published by the US Social Security Administration and it is meanly related to American Social Security issues.

In the same manner, regarding publications by West Europe, this area gets high percentages of the publications of the top ten journals of the list, being really important the $80.05 \%$ of Fiscal Studies $\left(6^{\text {th }}\right.$ in ranking) or the $66.02 \%$ of European Journal of Political Economy $\left(9^{\text {th }}\right.$ 
in ranking). Again in the last case, this percentage is explained by the fact that the journal is more focussed on European issues. The same explanation we could offer regarding the 92.13\% of Finanz Archiv (25 $5^{\text {th }}$ in ranking)

We ha also included the information for UK since this country reaches a great quantity of percentual points over West Europe area for some cases. In this sense, this country gets: 11.64 of 42.36 points for Journal of Public Economics ( $1^{\text {st }}$ in ranking), 68.73 of 80.05 points for Fiscal Studies, and 76.88 of 81.21 points for Policy Studies Journal $\left(27^{\text {th }}\right.$ in ranking) Regarding Fiscal Studies, the explanation since UK is publishing in this journal most than any other country in this area comes precisely from the 'Institute for Fiscal Studies', which points out as introducing its journal: "our research looks particularly at the UK tax system, considering the likely effects of fiscal policy on every section of the population".

Finally in table 1 we have included for each area the concept "Quality PE journals" as explained in [3], but first we include expression [2] as follows.

$A Q_{z}=\frac{\sum_{w=1}^{7} \sum_{i=1}^{31} \frac{1}{n} a z_{w i} P E I_{i}}{7}$

When $P E I_{i}$ refers to the impact factor of each journal $\mathrm{i}$ as calculated in expression [1] and $\frac{1}{n} a z_{w i}$ is the $1 / \mathrm{n}$ share of the area $\mathrm{z}$ publishing an article a in journal i. Then, we call $A Q_{z}$ the "Average Quality PE journals" putting together all z areas. In the same manner, and as calculated in expression (3), $Q_{z}$ is just the "Quality PE journals" for one area z. 
$Q_{z}=\frac{\sum_{i=1}^{31} \frac{1}{n} a z_{i} P E I_{i}}{A Q_{z}}$

Then, if we make $A Q_{z}=1$, any $Q_{z}$ bigger than 1 will imply that the area has a quality better than the average. Any $Q_{z}$ smaller that 1 will imply that the area has a quality worse than the average.

We focus on table 1, it is interesting to point out that, even if they are reaching the higher percentages regarding publications, the quality for USA and West Europe is just on the average, while UK alone gets 1.28 since it concentrates its publications in better journals. At the same time, Japan, which gets only $1.77 \%$ of total publications, reaches a quality of 0.95, almost the same that West Europe and USA.

Once we have analyzed how is publishing in each one of the 31 selected journals by areas of the world, next step is to study more deeply the situation for Italy, since it is the country we have selected for the present research. To undertake this issue, we have built table number 2 including 34 countries from both West and East Europe. The information is by percentages, being Europe equal to $100 \%$ for each one of the journals. In any case, we finally include just 6 countries in table 2 since they are the most important ones to compare with Italy.

[Table 2 about here]

As we did above, in this case we define $A Q_{c}$ like "Average Quality PE journals" as explained in expression [4], which is equivalent to expression [2] but referring to all c 
countries. As calculated in expression [5], $Q_{c}$ is just the "Quality PE journals" for one country c. Again, the explanation about expression [5] is equivalent to the one already done for expression [3]. Making $A Q_{c}=1$, any $Q_{c}$ bigger than 1 will imply that the country has a quality better than the average. Any $Q_{c}$ smaller that 1 will imply that the country has a quality worse than the average. The information regarding quality for each one of the countries is included at the last row on table 2.

$A Q_{c}=\frac{\sum_{k=1}^{34} \sum_{i=1}^{31} \frac{1}{l} a c_{k i} P E I_{i}}{34}$

$Q_{c}=\frac{\sum_{i=1}^{31} \frac{1}{l} a c_{i} P E I_{i}}{A Q_{c}}$

We have also ordered countries in table 2 taking into account the overall percentage of publications for each one of the countries: "Mean PE journals". The top six countries ranked in table 2 summarize $69.23 \%$ ( $\sum$ "Mean PE journals" for these six countries) of all articles published in the list of journals from 1995 to 2001 by European countries. These countries are by ranking Germany, UK, Netherlands, Italy, France, and Spain. Therefore, the other 28 countries just get $30.77 \%$ of articles published.

In fact, just Germany gets a Mean PE journals equal to $21.47 \%$ and it is leading seven journals: Economics of Governance, International Tax and Public Finance, European Journal of Political Economy, Public Choice, Kyklos, Social Security Bulletin (this journal 
is focussed on American issues, and Germany is the only country publishing on it), and Finanz Archiv. In the last case, Germany gets $80.76 \%$ of articles since this journal is primarily focussed on German issues. In the same manner, and as we already explained above, UK gets $85.85 \%$ of Fiscal Studies. Moreover this journal, UK is leading another six journals of the list, being among them the top one: Journal of Public Economics.

In this entire context, Italy gets $8.32 \%$ of total publications, being in the forth position after Netherlands, UK, and Germany. It is leading two journals: Public Finance and Management (together with Netherlands) and Journal of Public Finance and Public Choice/Economia delle Scelte Pubbliche. In the last case, even if this journal is meanly focussed in Italy, it is really more open than Fiscal Studies or Finanz Archiv since Italy publishes just $65.41 \%$ of the articles. This country is also in the second position regarding articles published on Economics and Politics, Economics of Governance, Public Choice, and Public Finance (together with Spain)

The quality of articles published by Italy is below the average (0.80), although it is smaller for Germany (0.71), even if this country is leading the ranking concerning number of articles published overall. This data could imply an excessive concentration on articles in journals with low impact factor $P E I_{i}$.

\section{A Ranking of Italian universities and other research institutions}

Overall the 5,474 articles analyzed in table 1 above, Europe (both West and East Europe) has published $38.2 \%$ (see table 1), that means 2,091 articles. And Italy has published $8.32 \%$ 
of these 2,091 articles (see table 2) in the 31 Public Economic journals listed in annex 1 from 1995 to 2001. Therefore, focussing now the study in Italy, we have considered which Italian Universities and other Research Institutions are publishing, proposing in table 3 a new ranking of universities and other institutions for this country ${ }^{7}$.

[Table 3 about here]

We have elaborated the ranking as follows: the points corresponding to each university are divided among each $1 / p$ universities publishing the same article. The weight of each article depends in the impact factor $P E I_{i}$ for each journal, as already estimated in annex 1 . The total points for each university/research institution (column 4 of table 3 ) is calculated as $\beta$ in expression [6] below.

$\beta=\sum_{i=1}^{31} \frac{1}{p} a u_{i} P E I_{i}$

Where $\frac{1}{p} a u_{i}$ is the $1 / \mathrm{p}$ share of the article a published by the university/research institution $\mathrm{u}$ in journal $\mathrm{i}$. Then, the value of $\beta$ offers the total amount of points reached by each university/research institution.

We have also calculated the 'Dispersion Factor (DF)' for each university/research institution (column 5 of table 3) as in expression [7] below.

\footnotetext{
${ }^{7}$ A good example doing rankings in a similar way than in this paper is Bairan (1994) This author also ranks universities just taking into account if their faculty is publishing in top journals or not.
} 


$$
D F=\frac{\sum_{i=1}^{31} \frac{1}{p} a u_{i} P E I_{i}}{\max \left(\frac{1}{p} a u_{i} P E I_{i}\right)}=\frac{\beta}{\max \left(\frac{1}{p} a u_{i} P E I_{i}\right)}
$$

Where $\max \left(\frac{1}{p} a u_{i} P E I_{i}\right)$ reflects the maximum amount of points considering every individual journal. Therefore, if one university concentrates its publications just in only one journal, DF takes value 1 . The dispersion factor increases if the university distributes the articles published in the selected list of journals, after taking into account the relative impact factor of each journal.

Taking into account DF, we can calculate 'DF points' for each university (column 6 of table 3) just multiplying the points obtained in column 4 by the DF indicator in column 5 . We have taken into account the values of this column regarding the ranking included in column 1. Column 7 shows the same ranking as in column 6 but after indexing the first ranked university to the value 100. Column 3 includes the number of articles for each university in all the 31 Public Economics journals.

The first place among the 54-universities/research institutions ranked in table 3 corresponds to the University of Torino, which is followed in second place by the University of Pisa and in third place by the Bocconi University. We have considered IGIER as an independent body from the Bocconi University. The other top ten places are covered by: the University of Roma "La Sapienza", the Bank of Italy, the University of Bologna, the University of 
Milano, the University of Firenze, the University of Pavia, and the University of Roma "Tor Vergata".

If we do not take into account the dispersion factor and we rank institutions considering only the global amount of points obtained (column 4 of table 3), the classification is then lead by the Bocconi University, followed by the University of Torino, and in the third place the University of Rome "La Sapienza". Other changes occur among the top ten institutions, but they remain all of them among the ten most productive institutions.

From data of table 3 we can also produce a measure of the average quality of the published contributions by each Italian university/research institution (column 8). It is simply obtained by dividing the total number of points (column 4) by the total number of articles (column 3). We have calculated the points of the first 20 ranked institutions, as only in that case the number of published articles is enough representative in order to reach conclusions about the average impact of the articles published. The results of the ranking change substantially, as IGIER takes the first place (with 633 points), followed by the University of Pavia (431 points) and University and Pisa (346 points). The remaining top ten institutions are: Bocconi University, University of Salerno, University of Milano, University "Cattolica del Sacro Cuore" of Rome, University of Torino, European University Institute, University of Rome "Tor Vergata". 


\section{Conclusions}

Using a new matching model approach this paper has presented a new ranking of Italian universities and other research institutions just taking into account their publications in a list of selected Public Economic journals. We would like to conclude pointing out that this ranking is interesting for several reasons. First, it tries to cover a lack of specific rankings in the publications market where each time more specific journals are appearing. Second, this ranking allows us to know which are the more productive Italian universities and other research institution in a more accurate way and not just concerning, for instance, economics departments. Third, it is easier to update if we want to introduce new Public Economics journals into the list, which will be practically impossible using other more general rankings. 


\section{References}

BAIRAN, E. I., 1994, "Institutional affiliation of contributors to top economic journals, 1985-1990”, Journal of Economic Literature, 32 (2), pp. 674-679.

BARRETT, Ch. - OLIA. A. - VON BAILEY, D., 2000, "Subdiscipline-specific journal rankings: whither Applied Economics?” Applied Economics, 32, pp. 239-252.

DAVIS, J. B., 1998, "Problems in using the Social Sciences Citation Index to rank Economic Journals", The American Economist, 42 (2), pp. 59-64.

KALAITZIDAKIS, P. - MAMUNEAS, Th. P. - STENGOS, Th., 2003, "Rankings of Academic Journals and Institutions in Economics", European Economic Review, forthcoming.

LABAND, D. - PIETTE, M., 1994, "The Relative Impact of Economics Journals", Journal of Economic Literature, 32 (2), pp. 640-666.

LIEBOWITZ, S. J. J.P. PALMER, J. P., 1984, “Assessing the Relative Impact of Economics Journals", Journal of Economic Literature, 22 (1), pp. 77-88.

MASON, P. M., STEAGALL, J. W. - FABRITIUS, M. M., 1997, "Economics Journal Rankings by Type of School: Perceptions Versus Citations", Quarterly Journal of Business and Economics, 36 (1), pp. 69-79.

PUJOL, F., 2003, "Ranking Public Economic Journals Following a Matching Model Approach", Working Paper 0414, School of Economics and Business Administration, University of Navarra, Pamplona, Spain. 
STIGLER, G. - STIGLER, S. - FRIEDLAND, C, 1995, "The Journals of Economics", Journal of Political Economy, 103, pp. 331-359. 
Table 1: Articles published in Public Economics Journals. Period 1995-2001 (by percentages)*

\begin{tabular}{|c|c|c|c|c|c|c|c|c|}
\hline $\begin{array}{c}\text { Rank } \\
\text { PE }\end{array}$ & Journal & USA & $\begin{array}{l}\text { West } \\
\text { Europe }\end{array}$ & UK** & $\begin{array}{c}\text { Asia } \\
\text { (except } \\
\text { Japan) }\end{array}$ & Japan & $\begin{array}{c}\text { East } \\
\text { Europe }\end{array}$ & $\begin{array}{c}\text { Latin } \\
\text { America }\end{array}$ \\
\hline 1 & Journal of Public Economics & 43.34 & 42.36 & 11.64 & 2.00 & 0.69 & 0.28 & 0.09 \\
\hline 2 & Journal of Public Economic Theory & 46.00 & 33.14 & 3.90 & 4.57 & 2.29 & 0.00 & 0.00 \\
\hline 3 & Economics and Politics & 56.03 & 22.21 & 0.46 & 1.37 & 1.83 & 0.00 & 1.37 \\
\hline 4 & Economics of Governance (up to July 2003) & 46.15 & 40.38 & 1.92 & 0.00 & 3.85 & 0.00 & 0.00 \\
\hline 5 & National Tax Journal & 91.10 & 4.40 & 2.04 & 0.37 & 0.00 & 0.00 & 0.00 \\
\hline 6 & Fiscal Studies & 8.69 & 80.05 & 68.73 & 0.00 & 0.00 & 0.00 & 0.00 \\
\hline 7 & Journal of Policy Reform & 38.53 & 29.76 & 6.70 & 3.87 & 0.00 & 4.51 & 3.48 \\
\hline 8 & International Tax and Public Finance & 22.79 & 56.87 & 7.96 & 1.90 & 3.49 & 0.82 & 0.00 \\
\hline 9 & European Journal of Political Economy & 18.11 & 66.02 & 7.78 & 2.83 & 0.92 & 1.01 & 0.84 \\
\hline 10 & Journal of Regulatory Economics & 68.07 & 15.02 & 5.23 & 1.45 & 0.85 & 0.00 & 0.24 \\
\hline 11 & Public Choice & 51.81 & 37.77 & 3.85 & 0.66 & 0.48 & 0.48 & 0.76 \\
\hline 12 & Kyklos & 20.95 & 61.98 & 9.65 & 2.07 & 0.00 & 0.00 & 0.26 \\
\hline 13 & Journal of Policy Analysis and Management & 90.58 & 2.91 & 0.73 & 0.16 & 0.00 & 0.00 & 0.00 \\
\hline 14 & Journal of Policy Modeling & 32.31 & 37.33 & 5.74 & 4.73 & 2.60 & 1.79 & 1.11 \\
\hline 15 & Canadian Public Policy & 10.00 & 3.93 & 2.68 & 0.32 & 0.00 & 0.00 & 0.00 \\
\hline 16 & Public Finance and Management & 38.65 & 33.13 & 0.00 & 3.68 & 1.84 & 0.00 & 0.00 \\
\hline 17 & Public Finance Quarterly & 69.46 & 15.51 & 3.88 & 6.14 & 0.00 & 1.94 & 0.00 \\
\hline 18 & Contemporary Economic Policy & 74.36 & 4.20 & 2.73 & 8.49 & 2.59 & 0.28 & 0.11 \\
\hline 19 & Public Finance & 20.93 & 46.65 & 6.18 & 6.18 & 10.29 & 0.00 & 0.00 \\
\hline 20 & Constitutional Political Economy & 42.96 & 42.96 & 4.75 & 1.76 & 0.70 & 0.70 & 1.41 \\
\hline 21 & $\begin{array}{l}\text { Journal of Public Finance and Public Choice / } \\
\text { Economia delle Scelte Pubbliche }\end{array}$ & 39.23 & 49.69 & 0.75 & 0.00 & 0.00 & 0.00 & 0.00 \\
\hline 22 & Public Finance Review & 69.56 & 14.49 & 2.91 & 3.49 & 0.35 & 0.00 & 0.70 \\
\hline 23 & Economic Analysis and Policy & 12.90 & 4.60 & 1.05 & 3.23 & 0.97 & 0.00 & 0.00 \\
\hline 24 & Social Security Bulletin & 97.68 & 0.71 & 0.00 & 0.00 & 0.00 & 0.00 & 0.00 \\
\hline 25 & Finanz Archiv & 3.23 & 92.13 & 0.54 & 0.22 & 1.29 & 0.00 & 0.00 \\
\hline 26 & Policy Sciences & 72.66 & 12.77 & 2.32 & 2.90 & 0.00 & 0.00 & 0.00 \\
\hline 27 & Policy Studies Journal & 7.79 & 81.21 & 76.88 & 0.52 & 0.00 & 0.52 & 0.00 \\
\hline 28 & Canadian Tax Journal & 17.38 & 0.99 & 0.00 & 0.00 & 0.00 & 0.00 & 0.00 \\
\hline 29 & Annals of Public and Cooperative Economics & 7.67 & 76.66 & 15.92 & 1.17 & 1.17 & 1.76 & 2.64 \\
\hline 30 & Public Budgeting and Finance & 90.16 & 2.37 & 0.55 & 1.09 & 0.55 & 0.18 & 0.00 \\
\hline \multirow[t]{3}{*}{31} & Bulletin for International Fiscal Documentation & 13.16 & 33.08 & 10.56 & 9.59 & 1.67 & 1.29 & 0.90 \\
\hline & Mean Public Economics (PE) journals & 46.95 & 37.73 & 7.24 & 2.32 & 1.77 & $\mathbf{0 . 4 7}$ & $\mathbf{0 . 4 7}$ \\
\hline & Quality PE journals (Average quality $=1$ ) & 1.03 & 0.99 & 1.28 & 0.82 & 0.95 & 0.57 & 0.52 \\
\hline
\end{tabular}

* Since we are excluding some international organizations, percentages for each one of the journals do not have to summarize $100 \%$ ** The percentage for UK is included within the total percentage for West Europe.

Source: Own elaboration. 
Table 2: Articles published in Public Economics Journals in some European countries. Period 1995-2001 (by percentages) Europe=100 for each journal and for "Mean PE journals"

\begin{tabular}{|c|c|c|c|c|c|c|c|}
\hline $\begin{array}{l}\text { Rank } \\
\text { PE }\end{array}$ & Journal & $\begin{array}{c}1 \\
\text { Germany }\end{array}$ & $\begin{array}{c}2 \\
\text { United } \\
\text { Kingdom } \\
\end{array}$ & $\begin{array}{c}3 \\
\text { Netherlands } \\
\end{array}$ & $\begin{array}{c}4 \\
\text { ITALY }\end{array}$ & $\begin{array}{c}5 \\
\text { France }\end{array}$ & $\begin{array}{c}6 \\
\text { Spain }\end{array}$ \\
\hline 1 & Journal of Public Economics & 11.19 & 27.47 & 9.86 & 3.14 & 10.46 & 3.65 \\
\hline 2 & Journal of Public Economic Theory & 12.65 & 11.78 & 3.45 & 10.35 & 18.11 & 13.78 \\
\hline 3 & Economics and Politics & 10.31 & 2.06 & 16.50 & 18.55 & 0 & 2.06 \\
\hline 4 & Economics of Governance (up to July 2003) & 23.81 & 4.76 & 4.76 & 19.05 & 9.52 & 9.52 \\
\hline 5 & National Tax Journal & 0 & 46.37 & 3.35 & 0 & 0 & 0 \\
\hline 6 & Fiscal Studies & 2.83 & 85.85 & 1.42 & 2.36 & 0 & 1.89 \\
\hline 7 & Journal of Policy Reform & 0 & 22.51 & 19.48 & 2.60 & 7.79 & 0 \\
\hline 8 & International Tax and Public Finance & 25.33 & 13.99 & 11.88 & 9.43 & 4.71 & 4.57 \\
\hline 9 & European Journal of Political Economy & 21.45 & 11.78 & 13.95 & 6.19 & 2.58 & 3.69 \\
\hline 10 & Journal of Regulatory Economics & 6.43 & 34.85 & 0 & 8.04 & 16.09 & 1.61 \\
\hline 11 & Public Choice & 20.20 & 10.19 & 12.21 & 15.12 & 1.83 & 3.73 \\
\hline 12 & Kyklos & 23.92 & 15.58 & 18.15 & 5.42 & 6.68 & 1.39 \\
\hline 13 & Journal of Policy Analysis and Management & 25.00 & 25.00 & 8.33 & 0 & 0 & 0 \\
\hline 14 & Journal of Policy Modeling & 5.77 & 15.38 & 24.52 & 7.69 & 4.73 & 1.44 \\
\hline 15 & Canadian Public Policy & 0 & 68.29 & 2.44 & 4.88 & 19.51 & 0 \\
\hline 16 & Public Finance and Management & 0 & 0 & 16.67 & 16.67 & 11.11 & 11.11 \\
\hline 17 & Public Finance Quarterly & 12.50 & 25.00 & 0 & 0 & 0 & 0 \\
\hline 18 & Contemporary Economic Policy & 4.03 & 65.09 & 8.06 & 0 & 0 & 8.06 \\
\hline 19 & Public Finance & 21.51 & 13.24 & 6.62 & 15.44 & 5.14 & 15.44 \\
\hline 20 & Constitutional Political Economy & 44.26 & 11.07 & 1.64 & 6.15 & 1.64 & 8.20 \\
\hline 21 & $\begin{array}{l}\text { Journal of Public Finance and Public Choice } \\
\text { / Economia delle Scelte Pubbliche }\end{array}$ & 0 & 1.50 & 0 & 65.41 & 6.02 & 12.03 \\
\hline 22 & Public Finance Review & 18.08 & 20.08 & 4.82 & 12.05 & 2.41 & 16.05 \\
\hline 23 & Economic Analysis and Policy & 10.53 & 22.81 & 0 & 0 & 0 & 0 \\
\hline 24 & Social Security Bulletin & 100.00 & 0 & 0 & 0 & 0 & 0 \\
\hline 25 & Finanz Archiv & 80.76 & 0.58 & 1.40 & 2.46 & 0 & 0.58 \\
\hline 26 & Policy Sciences & 30.30 & 18.18 & 18.18 & 0 & 0 & 0 \\
\hline 27 & Policy Studies Journal & 0 & 94.67 & 0 & 0 & 0 & 1.28 \\
\hline 28 & Canadian Tax Journal & 0 & 0 & 0 & 13.33 & 6.67 & 0 \\
\hline 29 & Annals of Public and Cooperative Economics & 12.29 & 20.77 & 0.76 & 9.85 & 14.84 & 8.41 \\
\hline 30 & Public Budgeting and Finance & 0 & 23.08 & 46.15 & 0 & 0 & 0 \\
\hline \multirow[t]{3}{*}{31} & Bulletin for International Fiscal Documentation & 14.54 & 31.91 & 13.24 & 5.45 & 5.84 & 3.89 \\
\hline & Mean PE journals & 21.47 & 19.19 & 9.59 & 8.32 & 5.91 & 4.75 \\
\hline & Quality PE journals (Average quality=1) & 0.71 & 1.30 & 1.00 & 0.80 & 1.31 & 0.99 \\
\hline
\end{tabular}

Source: Own elaboration. 
Table 3: Top Universities and other institutions in Italy regarding Public Economics Journals.

Period 1995-2001

\begin{tabular}{|c|c|c|c|c|c|c|c|}
\hline $\begin{array}{c}\text { Rank } \\
\text { (1) }\end{array}$ & $\begin{array}{c}\text { University/Institution } \\
\text { (2) }\end{array}$ & $\begin{array}{c}\text { Articles } \\
\text { (3) }\end{array}$ & $\begin{array}{c}\text { Points ( } \beta \text { ) } \\
\text { (4) }\end{array}$ & $\begin{array}{c}\text { Dispersion } \\
\text { Factor (DF) } \\
(5)\end{array}$ & $\begin{array}{c}\text { DF Points } \\
\text { (6) }\end{array}$ & $\begin{array}{c}\text { Final } \\
\text { Points } \\
(7)\end{array}$ & $\begin{array}{l}\text { Average } \\
\text { Quality } \\
\text { (8) }\end{array}$ \\
\hline 1 & University of Torino & 10.25 & $2,139.40$ & 3.62 & $7,741.40$ & 100 & $\begin{array}{r}208.72 \\
(8)\end{array}$ \\
\hline 2 & University of Pisa & 6.00 & $2,079.18$ & 3.21 & $6,669.27$ & 86.15 & $\begin{array}{r}346.53 \\
\text { (3) }\end{array}$ \\
\hline 3 & University of Bocconi & 9.33 & $2,858.74$ & 2.05 & $5,870.84$ & 75.84 & $\begin{array}{r}306.29 \\
(4)\end{array}$ \\
\hline 4 & University of Roma "La Sapienza" & 14.00 & $2,110.59$ & 2.48 & $5,233.30$ & 67.60 & 150.76 \\
\hline 5 & Bank of Italy & 9.50 & $1,493.18$ & 2.25 & $3,356.03$ & 43.35 & 157.18 \\
\hline 6 & University of Bologna & 6.17 & $1,155.52$ & 2.87 & $3,314.92$ & 42.82 & 187.38 \\
\hline 7 & University of Milano & 6.50 & $1,480.91$ & 2.06 & $3,043.28$ & 39.31 & $\begin{array}{r}227.83 \\
(6)\end{array}$ \\
\hline 8 & University of Firenze & 6.00 & $1,021.41$ & 2.83 & $2,895.45$ & 37.40 & 170.24 \\
\hline 9 & University of Pavia & 3.17 & $1,364.93$ & 2.11 & $2,874.19$ & 37.13 & $\begin{array}{r}430.99 \\
(2)\end{array}$ \\
\hline 10 & University of Roma "Tor Vergata" & 5.25 & $1,011.17$ & 1.56 & $1,577.40$ & 20.38 & $\begin{array}{r}192.60 \\
(\mathbf{1 0})\end{array}$ \\
\hline 11 & $\begin{array}{l}\text { IGIER (“Innocenzo Gasparini” Institute } \\
\text { for Economic Research) }\end{array}$ & 1.50 & 950.37 & 1.64 & $1,557.22$ & 20.12 & $\begin{array}{r}632.18 \\
(1)\end{array}$ \\
\hline 12 & University of Roma III & 6.00 & 907.36 & 1.68 & $1,519.94$ & 19.63 & 151.23 \\
\hline 13 & University of Catania & 5.00 & 673.25 & 2.18 & $1,464.37$ & 18.92 & 134.65 \\
\hline 14 & University of Siena & 5.50 & 586.97 & 1.90 & $1,113.09$ & 14.38 & 106.72 \\
\hline 15 & University of Napoli & 5.50 & 569.48 & 1.84 & $1,047.75$ & 13.53 & 103.54 \\
\hline 16 & University of Messina & 5.67 & 693.87 & 1.49 & $1,036.97$ & 13.40 & 122.45 \\
\hline 17 & University of Trento & 6.50 & 670.71 & 1.48 & 995.43 & 12.86 & 103.19 \\
\hline 18 & $\begin{array}{l}\text { University "Cattolica del Sacro Cuore", } \\
\text { Roma }\end{array}$ & 2.25 & 485.76 & 2.00 & 972.05 & 12.56 & $\begin{array}{r}215.90 \\
(7)\end{array}$ \\
\hline 19 & European University Institute & 1.92 & 399.75 & 2.25 & 899.85 & 11.62 & $\begin{array}{r}208.20 \\
(9)\end{array}$ \\
\hline 20 & University of Salerno & 1.50 & 434.68 & 1.62 & 703.47 & 9.09 & $\begin{array}{r}289.78 \\
(5)\end{array}$ \\
\hline 21 & University of Chieti & 1.00 & 648.19 & 1.00 & 648.19 & 8.37 & \\
\hline 22 & University of Brescia & 3.17 & 227.19 & 2.59 & 589.19 & 7.61 & \\
\hline 23 & $\begin{array}{l}\text { GRETA ("Gruppi di Ricerca Economica } \\
\text { Teorica e Applicata") Associati }\end{array}$ & 0.84 & 542.32 & 1.00 & 542.32 & 7.01 & \\
\hline 24 & University of Verona & 1.50 & 352.65 & 1.34 & 471.32 & 6.09 & \\
\hline 25 & $\begin{array}{l}\text { ICER (International Centre for } \\
\text { Economic Research), Torino }\end{array}$ & 2.50 & 279.29 & 1.44 & 403.21 & 5.21 & \\
\hline
\end{tabular}




\begin{tabular}{|c|c|c|c|c|c|c|}
\hline 26 & University of Padova & 2.00 & 345.25 & 1.07 & 367.77 & 4.75 \\
\hline 27 & University of Milano-Bicocca & 1.17 & 353.94 & 1.02 & 361.13 & 4.66 \\
\hline 28 & University of Bergamo & 0.67 & 198.98 & 1.81 & 359.32 & 4.64 \\
\hline 29 & University of Macerata & 1.00 & 267.22 & 1.03 & 274.46 & 3.55 \\
\hline 30 & University of Genova & 1.50 & 190.41 & 1.23 & 234.28 & 3.03 \\
\hline 31 & University of Venezia "Ca'Foscari" & 0.67 & 140.82 & 1.28 & 179.97 & 2.32 \\
\hline 32 & University of Palermo & 1.25 & 117.66 & 1.52 & 178.91 & 2.31 \\
\hline 33 & University of Udine & 1.00 & 177.58 & 1.00 & 177.58 & 2.29 \\
\hline 34 & University of Parma & 0.25 & 174.00 & 1.00 & 174.00 & 2.25 \\
\hline 35 & University of Sassari & 0.25 & 162.05 & 1.00 & 162.05 & 2.09 \\
\hline 36 & University of Perugia & 1.00 & 102.35 & 1.32 & 135.37 & 1.75 \\
\hline 37 & Bank of Roma & 0.25 & 130.08 & 1.00 & 130.08 & 1.68 \\
\hline 38 & $\begin{array}{l}\text { "Istituto Nazionale per lo Studio della } \\
\text { Congiuntura", Roma }\end{array}$ & 1.00 & 96.78 & 1.00 & 96.78 & 1.25 \\
\hline 39 & $\begin{array}{l}\text { "Istituto di Economia e Politica } \\
\text { Agraria", Verona }\end{array}$ & 0.50 & 77.38 & 1.00 & 77.38 & 1.00 \\
\hline 40 & Banca Commerciale Italiana & 0.50 & 77.38 & 1.00 & 77.38 & 1.00 \\
\hline & University of Eastern Piedmont & 0.75 & 50.97 & 1.43 & 72.86 & 0.94 \\
\hline & University dell'Insubria & 0.25 & 65.97 & 1.00 & 65.97 & 0.85 \\
\hline & University of Ancona & 0.33 & 59.19 & 1.00 & 59.19 & 0.76 \\
\hline & University of Pescara & 0.50 & 48.39 & 1.00 & 48.39 & 0.63 \\
\hline & $\begin{array}{l}\text { LUM (“Libera Università } \\
\text { Mediterranea"), Bari }\end{array}$ & 0.50 & 48.39 & 1.00 & 48.39 & 0.63 \\
\hline & "Istituto Universitario Navale di Napoli" & 0.50 & 48.39 & 1.00 & 48.39 & 0.63 \\
\hline & University of IUAV, Venezia & 0.17 & 43.98 & 1.00 & 43.98 & 0.57 \\
\hline & "Sede di Scienze Politiche", Pisa & 1.00 & 32.05 & 1.00 & 32.05 & 0.41 \\
\hline & $\begin{array}{l}\text { DEPA ("Dipartimento di Economia e } \\
\text { Politica Agraria"), Milano }\end{array}$ & 0.50 & 24.27 & 1.00 & 24.27 & 0.31 \\
\hline & "Centro Studi Confindustria", Roma & 0.50 & 16.03 & 1.00 & 16.03 & 0.21 \\
\hline & University of Ferrana I & 1.00 & 14.10 & 1.00 & 14.10 & 0.18 \\
\hline & $\begin{array}{l}\text { "Consiglio Nazionale delle Ricerche", } \\
\text { Roma }\end{array}$ & 1.00 & 14.10 & 1.00 & 14.10 & 0.18 \\
\hline & $\begin{array}{l}\text { "Consiglio Nazionale dell'Economia e } \\
\text { del Lavoro", Roma }\end{array}$ & 0.50 & 7.05 & 1.00 & 7.05 & 0.09 \\
\hline
\end{tabular}

Source: Own elaboration. 
Annex 1: Ranking of Public Economics and Neighbor Discipline Journals Period 1995-2001.

\begin{tabular}{|c|c|c|c|c|}
\hline $\begin{array}{c}\text { Rank } \\
\text { (1) }\end{array}$ & $\begin{array}{c}\text { Rank } \\
\text { PE Core } \\
(2) \\
\end{array}$ & $\begin{array}{c}\text { Articles } \\
\text { (3) }\end{array}$ & $\begin{array}{c}\text { Journal } \\
(4)\end{array}$ & $\begin{array}{l}\text { Points } \\
\text { (5) }\end{array}$ \\
\hline 1 & & 165 & Carnegie-Rochester Conference Series on Public Policy & 129.31 \\
\hline 2 & & 275 & Social Choice and Welfare & 76.37 \\
\hline 3 & & 77 & Economic Policy & 69.60 \\
\hline 4 & 1 & 518 & Journal of Public Economics & 64.82 \\
\hline 5 & 2 & 85 & Journal of Public Economic Theory & 59.12 \\
\hline 6 & & 41 & American Law and Economics Review & 53.43 \\
\hline 7 & 3 & 105 & Economics and Politics & 52.03 \\
\hline 8 & 4 & 53 & Economics of Governance (up to July 2003) & 44.86 \\
\hline 9 & 5 & 344 & National Tax Journal & 33.79 \\
\hline 10 & 6 & 137 & Fiscal Studies & 33.22 \\
\hline 11 & 7 & 63 & Journal of Policy Reform & 31.93 \\
\hline 12 & & 308 & Journal Urban Economics & 26.86 \\
\hline 13 & & 228 & Regional Science and Urban Economics & 26.85 \\
\hline 14 & 8 & 217 & International Tax and Public Finance & 26.39 \\
\hline 15 & & 291 & Journal of Health Economics & 19.08 \\
\hline 16 & 9 & 295 & European Journal of Political Economy & 17.76 \\
\hline 17 & 10 & 210 & Journal of Regulatory Economics & 15.89 \\
\hline 18 & 11 & 590 & Public Choice & 15.48 \\
\hline 19 & 12 & 186 & Kyklos & 12.91 \\
\hline 20 & 13 & 209 & Journal of Policy Analysis and Management & 11.33 \\
\hline 21 & 14 & 265 & Journal of Policy Modeling & 9.68 \\
\hline 22 & 15 & 268 & Canadian Public Policy & 9.13 \\
\hline 23 & 16 & 25 & Public Finance and Management & 8.97 \\
\hline 24 & 17 & 53 & Public Finance Quarterly & 8.10 \\
\hline 25 & 18 & 297 & Contemporary Economic Policy & 7.23 \\
\hline 26 & 19 & 94 & Public Finance & 7.13 \\
\hline 27 & & 82 & Journal of Income Distribution & 6.31 \\
\hline 28 & 20 & 136 & Constitutional Political Economy & 6.13 \\
\hline 29 & 21 & 65 & Journal of Public Finance and Public Choice / & 4.99 \\
\hline & & & Economia delle Scelte Pubbliche & \\
\hline 30 & 22 & 147 & Public Finance Review & 4.85 \\
\hline
\end{tabular}




\begin{tabular}{|r|r|r|l|r|}
31 & $\mathbf{2 3}$ & 101 & Economic Analysis and Policy & $\mathbf{4 . 2 7}$ \\
32 & & 272 & Journal of Post Keynesian Economics & 3.69 \\
33 & $\mathbf{2 4}$ & 140 & Social Security Bulletin & $\mathbf{3 . 6 7}$ \\
34 & $\mathbf{2 5}$ & 158 & Finanz Archiv & $\mathbf{3 . 2 1}$ \\
35 & & 55 & Journal of Regional Analysis and Policy & 3.18 \\
\hline 36 & & 229 & Journal of Socio-Economics & 3.13 \\
37 & $\mathbf{2 6}$ & 132 & Policy Sciences & $\mathbf{2 . 1 4}$ \\
38 & $\mathbf{2 7}$ & 96 & Policy Studies Journal & $\mathbf{1 . 9 8}$ \\
39 & $\mathbf{2 8}$ & 378 & Canadian Tax Journal & $\mathbf{1 . 7 7}$ \\
40 & $\mathbf{2 9}$ & 175 & Annals of Public and Cooperative Economics & $\mathbf{1 . 4 1}$ \\
\hline 41 & & 320 & American Journal of Economics and Sociology & 1.14 \\
42 & $\mathbf{3 0}$ & 188 & Public Budgeting and Finance & $\mathbf{0 . 6 0}$ \\
43 & & 253 & Environment and Planing C: Government and Policy & 0.23 \\
44 & $\mathbf{3 1}$ & 437 & Bulletin for International Fiscal Documentation & $\mathbf{0 . 0 7}$ \\
45 & & 55 & Public Administration Review & 0.00 \\
46 & & 41 & Journal of Public and International Affairs & 0.00 \\
\hline Total & & 8,832 & Total / Average & 20.68 \\
\hline Total & & $\mathbf{6 , 1 0 2}$ & Total Core / Average & $\mathbf{1 7 . 1 6}$ \\
Core & & & & \\
\hline
\end{tabular}

Source: Pujol (2003) and own elaboration. 